\title{
LEARNING TO TALK
}

\section{SPRAGUE DE CAMP}

\section{Lansdowne, Pennsylvania}

7 HIs is an account of the phonetic aspects of how one small boy learned 1 to speak his native English. The subject was born 15 January, 1941, in New York City. In September, 1942, he was moved to a suburb of Philadelphia, where he has lived since. At the time of writing (April, 1945) he is fairly healthy, nervous, over-active, self-assertive, frequently 'difficult,' garrulous, and gregarious.

His principal associates have been his father, mother, and mother's uncle. All are college-educated New Yorkers. Their speech is normal, with the following differences: The mother's uncle consistently 'drops r's' and uses [3I] in words like bird. The mother has had speech-training and done speech-teaching. Her usage in words like ask and words with final and preconsonantal $\mathrm{r}$ 's is erratic. She says [æsk] or [ask], [bærd] or [b3d]. The father spent many of his formative years in Upstate New York and California, and consistently sounds final and preconsonantal r's.

The child's speech may have been retarded by whooping-cough at the age of one, and by being, during the subject period, an only child. His passive vocabulary developed normally, and by the end of his second year he is believed to have understood several hundred words.

At 12 months his babble consisted of repetition of several simple open syllables: [mãmãmã], [jała ja], [gurgurgur], [mĩmĩmĩ], etc. The consonants were $[\mathrm{m}],[\mathrm{v}],[\mathrm{f}],[\mathrm{j}],[\mathrm{j}],[\mathrm{g}]$. The vowels were [i], [u] , and a variable low vowel $\left[\mathfrak{l}^{\mathrm{a}} / \mathrm{a} / \mathrm{a} / \mathrm{e}\right]$, here transcribed [a]. The syllable [mã] is believed to have signified annoyance and [ja] contentment. [i:] was a cry of pleasure.

By 18 months he had added $[\mathrm{b}],[\mathrm{m}],[\mathrm{n}],[\mathrm{k}],[\mathrm{d}]$, and [w]; also a back round vowel varying from $[\mathrm{p}]$ to $[\mathrm{u}]$.

At 20 months he tried a word, car [ka], but after a few trials dropped it and did not take it up again for several months. His next attempt was gone

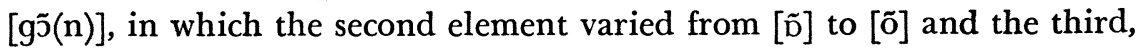
when present, might be $[\mathrm{n}],[\mathrm{m}]$, or [ũ]. For three months this word constituted his entire vocabulary. He used it frequently and always appositely.

Between 18 and 24 months he added [h], [p], [t], and [s]. He dropped [ur] and the palatal and labiodental stops and nasals. The low vowel narrowed its range of variation down to $[\mathrm{a} / \mathrm{a}]$. The back-round vowel split into two: $[\mathrm{p} / \mathrm{o}]$ and $[\mathrm{o} / \mathrm{ou} / \mathrm{u}]$.

At 23 months his babble was varied to include alternations of syllables: [gogugogu], [dadidadi], [aiaiai], [uiuiui]. He had added the following words: hole $[\mathrm{ho}(\mathrm{u})]$, meow (cat) [iau], woof-woof (dog) [u'v], moo (cow) 
[mu:]. Despite these examples of onomatopoeia, his parents have carefully refrained from using baby-talk on him.

Between twenty-three and twenty-four months he began to learn words in earnest. He also acquired an interest in printed letters, frequently pointing to them and asking '[bi]?' (meaning 'What's this called?'), with the result that for several weeks a quarter of his rapidly expanding vocabulary consisted of names of letters. At twenty-four months his active vocabulary

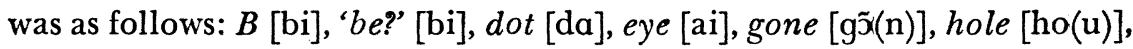
hot [ha], meow [iau], moo [mu], more [moi], $O[\mathrm{o}(\mathrm{u})], S[\mathrm{~s}:]$, star ("pentagram') [tai], woof-woof ['U'u]. Nearly all syllables were open, and his use of [i] for final [ð] became general as he learned more words of this type. At this time he made his first attempts at sentences: 'All gone' [o gon] and 'Gone daddy' [g̃ dadi].

Thenceforth the rate of addition of new words increased until it reached a maximum, at twenty-six months, of about a dozen new words a dayor at least too many to keep accurate count of. The words were nearly all fitted into the phonetic pattern previously laid down, with the following additions: he experimented with new diphthongs, differentiated between $[\mathrm{o}(\mathrm{u})]$ and $[\mathrm{u}]$ (though not consistently), and added a final [P].

At twenty-five months he was saying: $A$ [ei], all [o], $B$ [bi], baby [bibip], ball [bo], bar [bai, bau], bobby (pin) [babi'], book [bo'], bow (of a ship) [bai, bau], bowl [bo], boy [boi], $C$ [si], car [kai, kau], cold [ko], $D$ [di], Daddy [dadi'], door [doi], dot [da?], Dotty [dati?], E [i], ear [io], eye [ai],

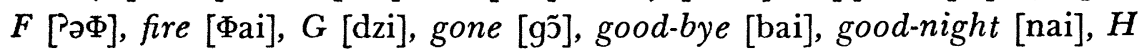
[ip], hair [hei], hole [ho], (shoe-)horn [h5̃], hot [ha'], I (the letter) [ai], I see! [aisi], $J$ [zi], knee [ni], knife [nai], knot [na?], L [io], light [jai’], man [mõ], meow [jau], moo [mu], moon (crescent) [mũ], more [moi], Mummy

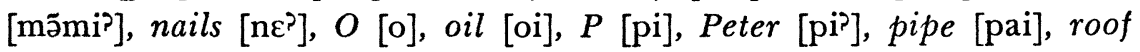
[vuథ], $S$ [s:], star [tai], $T$ [ti], tie [tai], toe [to], towel [tau], toy [toi], $U$

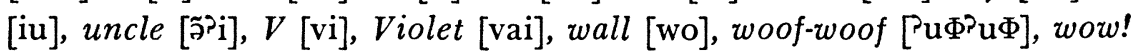
[wau], $Y$ [wai, wau].

It will be seen that open monosyllables with simple initial consonants still strongly predominated. The free vowels in the foregoing list were all long; the checked short. Hence there was a distinction between, for instance, book [bo'] and bowl [bo:]. There was also a distinction between nasal and unnasalized vowels, as in moo [mu:] and moon [mũ:]. Diphthongs were level, with the initial and final qualities more prominent than the connecting glide, so that they gave the effect of two separate vowel phonemes in succession. Free [o] was [o:] or, less often [ou]. Fricatives, true glides ([j], [w]), and mid-front vowels were just appearing. Disyllables had no stress-accent. 
During the following weeks his vowel-pattern rapidly elaborated, until at twenty-six months it comprised the following:

(1) Five longs (open syllables only): [i:], [a:], [o:], [u:], [3:], as in $m e$ [mi:], bath [ba:], no [no:], new [nu:], bird [b3:].

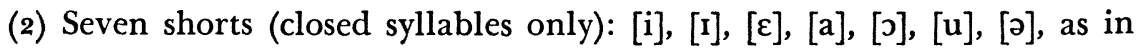
piece [pis], picture [pIs], seven [hedn], off [af], water [^], boot [bu?], milk [mə?].

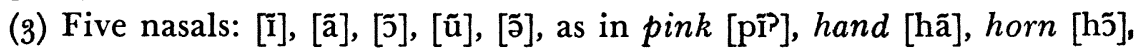

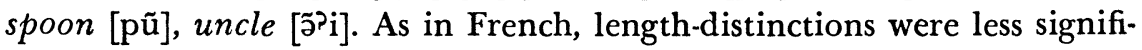
cant in nasal vowels than in unnasalized vowels.

(4) Seven diphthongs: [ei], [ai], [oi], [iu], [au], [ãi], [j̃i], as in chair [hei], typewriter [tai ], story [toi], pouch [pau], $U$ [iu], sign [hãi], arm [j̃i].

Other combinations appeared at this time, but so evanescently that it was hard to tell whether they should have been considered part of the child's phonetic equipment, as in the case of tree [həi:]. The child's pronunciation was changing so rapidly that no rigorously accurate analysis of his speech-development would have been possible except by watching him day and night to record every sound. Still, the foregoing classification of vowels gives a pretty good idea of his phonetic organization at the timea pattern consistent enough within itself, but quite unlike that of normal adult English speech. His [a] phonemes were just beginning to split into front and back varieties. He experimented with centering diphthongs, as in star [tai, tau, tar]. More closed syllables appeared, as in watch [va $\left.{ }^{3} \mathrm{c}\right]$, toys [tois], yes [zes], brush [ba'ç], box [ba', ba's, baxs], match [mats, max], mouth [mauf, maus], teeth [tits, tið].

Confusion existed between $[\mathrm{v}]$ and $[\mathrm{w}]$; between $[\mathrm{h}]$, [s], and [ [], as in fish [Iç], [ss], shoe [çu:], [hu:]; between [t] and [k], as in coat [tu?, $\mathrm{ku}^{\mathrm{P}}$ ]; between [o] and [u], as in hole [ho:], [hu:]; between [ei] and [ai], as in grapefruit [vai’fu].

His attempts to learn words with final stops and final syllabic nasals at the same time resulted in bacon [bei?, beipm], bed [bedn]], egg [ei, eidn], napkin [na?n], pad [pa, padn] ], thank you [ã?n] and wagon [vædn, væ’n, wæi].

Other attempts at new combinations were chair [çi:, hei, heiə], pill [peiə, peu], stair [tziə], toilet [toii], and $W$ [bədəbədə]. On ${ }_{15}$ March, 1943, a check, as accurate as circumstances permitted, showed an active vocabulary of 173 words.

At twenty-seven months he was assembling three and four word sentences, like 'Nice day go out.' He was struggling with polysyllables, as garter

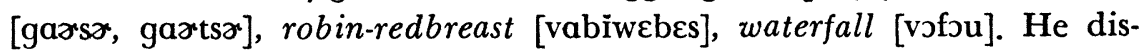
tinguished regularly between $[a]$ and $[æ]$, and between $[0],[u]$, and $[u]$. 
He had not mastered $[\mathrm{hw}],[\theta],[\delta],\left[\int\right],[\mathrm{t} f],[\mathrm{z}],[\mathrm{d} z],[\mathrm{l}]$, and [r]. Hence whistle was [fisu], through [siu], table [teibp] , detach [əntæ'ç].

At twenty-nine months he had a nearly complete set of vowels: [i], [r],

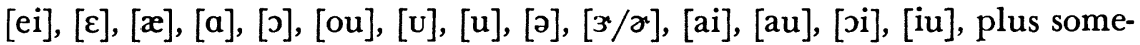

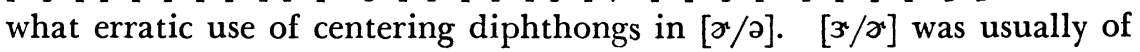
the unretroflexed type. The isolated nasal vowels, as in candy [kãi], had largely disappeared, though he still sometimes confused nasal consonants. Initial consonant clusters were commonly represented by [f], as in train [fein], straw [fo]. Initial [1] was usually represented by [j], as in library [jaibei], or [w], as in lot [wa $\left.{ }^{2}\right]$. Final and preconsonantal [1] became an [u]-vowel or glide. Other [l]'s were usually omitted, as in globe [goub]. He did not, then or long after, distinguish clearly between [il], [Il], [ju], $[\mathrm{lu}]$, and [u]. Hence he pronounced wheel, feel, fill, and few alike as [fiu]; blue as [biu]; too as [tu:] or [tiu]; can you as [kænu]. Final [t] developed now for the first time, as in bat $\left[\mathrm{bæt}^{\mathrm{h}}\right]$.

At thirty months train had become [tmein]. He was using fairly complete sentences, such as 'Take my bib off' [tei mai brb əf]; 'Uncle punch holes in paper' [ə̃̃: pãs houz in peipər]. He was just mastering the personal pronouns, and still said 'my' for 'your.'

At thirty-two months [v] and [w] became general for all prevocal [l]'s, as in hello [hə'vau], light [wait]. Stress-accent finally appeared.

During the following month the child was sent to nursery school. To his parents' dismay he immediately began broadening his diphthongs in the manner characteristic of Philadelphia, where, in extreme cases, [i], [e], [ar], [au], [að], [эr], [əæ], [o], and [u] become respectively [ëi], [ær], [pr], [æu], [pr], [or], [or], [ש̈U], and [rü]. ${ }^{1}$ The parents have struggled with indifferent results against this dialect ever since. Sample sentences of this

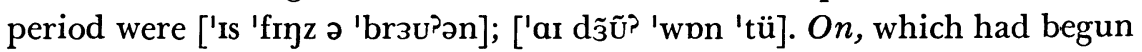
existence as [ãn], changed to [on] in accordance with local usage.

At this time [ $\Lambda]$ became differentiated from [ə] in quality. Diphthongs were divided into rising and falling; e.g. the level diphthongs [ai] and [iu] became [ẵ] and [ju]. His [r] was now perfect, though [w] was still occasionally substituted for it. It had developed from $[\mathrm{w}]$ and $[\mathrm{v}]$ through $[\mathrm{M}]$, and [u], as in tree [tmi:], and Frank [fur $\tilde{x}^{P}$ ], to an unretroflexed glide [r], and finally to the common retroflexed glide.

By thirty-five months, except for the affricates (which he was beginning to master), [1], $[\theta]$, [ð], and the more difficult consonantal clusters, his assortment of consonants was for practical purposes complete. Sentences were: 'Look at my little lamb' ['wukĩ mar 'wıu 'w ̃̃:m]; 'This is the train

1. See R. W. Tucker, 'Notes on the Philadelphia Dialect,' $A m$. Sp. 19: 37. 
track' ['wis Iz ə 'trein 'træk]; 'Uncle's through with the bathroom' [' $\wedge$ jkiz 'fu wif 'bæfrum], 'You can't see the wheels' [ju 'k $\tilde{x}^{2}$ 'si ə 'hwiuz]; 'I want a panda' [a 'vãt a 'pe:ndə].

Since then the growth of the child's vocabulary has continued, but his pronunciation has changed with extreme slowness. At thirty-nine months he was saying: [ga'baI 'deədïi, 'sïi jə 'weıdə ' $\supset: n]$; [aI 'drıjk meI tə'mer'dzüs]; ['pu 'huk 'rar in ' $x$ 'wru hou 'rar 'nrə a 'farə,pwers]; ['dæ:drii,

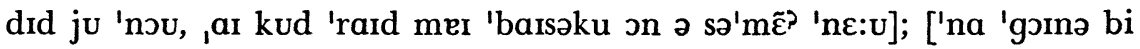
'disə'porntad 'nœu, ain 'nv:t].

At present, at fifty-one months, he is just beginning to develop normal $[1],[\theta]$, and [ $\varnothing]$. When this change is complete there will be little left of a specifically infantile nature in his speech. During the summer months the Philadelphia dialect gradually disappears, but it returns each fall with the reopening of nursery school. ${ }^{2}$

It is suggested that a number of studies of the phonetic development of children, at which this article is an attempt, would shed light on certain recurrent phenomena in the evolution of language: for instance, the breakdown of [1] in Latin, whereby platea became Italian piazza and alba became French aube; the parallel change that has occurred in Scottish English; ${ }^{4}$ the glottalization of medial and final [t] that has become common in many dialects of English; the wholesale loss of final consonants in French and Chinese, and the development of phonemic nasalization in French and Portuguese. It is a platitude that a principal cause of phonetic change is the survival into adult life of phonetic infantilism; but much remains to be done in working out the precise rationale of the process that results in, let us say, one dialect's losing its final r's while another dialect of the same language keeps them.

One point might be made now: If the child's speech is analyzed at any stage through which it has passed so far, it is seen to be erratic; that is, it contains phonetic anomalies and exceptions that do not fit into a neat phoneme pattern. It is always in the midst of splitting a phoneme into two, or developing a new sound, or abandoning an old one that did not fit, or using two widely different members of the same diaphone. Nor do I see reason to expect it ever to reach a perfectly stable and consistent state. As far as my own observations go, all normal speech, at least in this

2. In the eleven months since this was written, the subject has developed a very

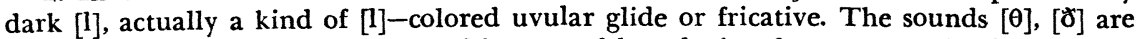
not yet established. The Philadelphian vowel-broadening has apparently disappeared for good.

3. See A. Lloyd James, Historical Introduction to French Phonetics, pp. 125, 131 ff.

4. See Grant and Dixon, Manual of Modern Scots, p. 17 f.; also E. Dieth, A Grammar of the Buchan Dialect, p. 100 ff. 
part of the world, is somewhat erratic. ${ }^{5}$ Even if our subject becomes speechconscious and deliberately purges his speech of its inconsistencies, he will

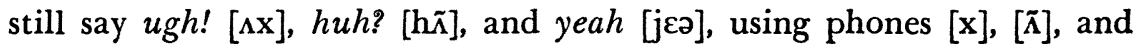
$[\varepsilon ə]$ which do not fit into his general phonemic pattern. ([ॄə] is anomalous because he uses [ $\varepsilon x]$ in words like bear.) It would seem that such anomalies occur in other languages; Iraqi Arabic has a word [zjẽ], 'okay,' which is described as 'apparently outside the phonological system of the language.' 6

This is not to deprecate the phoneme theory or to urge that erraticisms be taught students. It is merely to emphasize that erratic speech is normal speech, and that the relation between a textbook dialect, neatly classified into consistently used phonemes, and the speech on any given day of any given real human being, is analogous to that between a geometrician's ideal cube and one of the cubical blocks from our subject's toy set-worn edges, chipped paint, tooth-marks, and all.

5. Cf. D. Jones, 'r-kıləd vauəlz,' Le Maître Phonètique, 1940, p. 56. On p. 60 Dr. Jones says, 'Erratic speech must, I think, be regarded as abnormal speech.'

6. C. Rabin, 'ira:ki arabik,' Le Maître Phonètique, 194o, p. 44 f. 